\title{
PReS-FINAL-2129: Whole-body versus localized magnetic resonance imaging in the assessment of juvenile dermatomyositis
}

\author{
A Madeo ${ }^{1 *}$, MB Damasio², M Dellepiane ${ }^{1}$, A Providenti $^{1}$, D Beleva $^{1}$, A Buoncompagni ${ }^{1}$, A Beltramo ${ }^{1}$, N Ruperto ${ }^{1}$, \\ A Martini ${ }^{1}$, C Malattia $^{1}$
}

From 20th Pediatric Rheumatology European Society (PReS) Congress

Ljubljana, Slovenia. 25-29 September 2013

\section{Introduction}

MRI represents a promising tool in the assessment of disease activity in juvenile dermatomyositis (JDM). Watersensitive sequences are very sensitive to the presence of inflammation and have the potential to support diagnosis, guide muscle biopsy and monitor treatment response. So far, all MRI studies in JDM focused on pelvic and thigh musculature. Whole-body(WB)-MRI screens the entire body with the advantage to evaluate much larger areas of muscles as well as subcutaneous fat tissue.

\section{Objectives}

To compare WB-MRI and thighs-MRI in the assessment of disease activity in JDM.

\section{Methods}

WB-MR images were obtained from 43 JDM patients and 43 controls using a 1.5 Tesla MRI scanner and STIR sequences. Muscle signal abnormalities were scored by 2 independent readers in 36 muscular groups using a 0-2 point scale; perifascicular and subcutaneous tissue inflammation were evaluated using a binary scale on 8 sites (arm, forearm, thigh and lower leg bilaterally). Two different readers separately scored, on the same WB-MR images, pelvic and thigh muscles bilaterally (gluteal muscles, hamstrings, quadriceps and adductors) as well as the presence of thigh subcutaneous soft-tissue oedema and perifascicular oedema. WB-MRI and thighs MRI scores were compared in terms of reliability, construct validity, discriminant ability and responsiveness.

${ }^{1}$ Pediatrics, Istituto G. Giannini, Genova, Italy

Full list of author information is available at the end of the article

\section{Results}

Thighs subcutaneous and myofascial signal abnormalities were detected in $8 / 43(18.6 \%)$ and in $12 / 43$ (27.9\%) patients respectively. WB-MRI revealed inflammatory involvement of myofascial and subcutaneous areas other than the thigh in $8 / 43(18.6 \%)$ and $10 / 43(23.2 \%)$ patients, respectively Concordance between WB and thigh MRI scores in the evaluation of myofascial and subcutaneous tissue was moderate (myofascial scores $r_{s}=0.59$, subcutaneous scores $\left.r_{s}=0.69\right)$. Although concordance in detecting muscle inflammation between thigh and WB-MRI muscle scores was excellent $\left(r_{s}=0.97\right)$, two patients with negative thigh-MRI showed muscle signal abnormalities in muscle groups different from the thigh. Inter-reader agreement was excellent for both thigh-MRI and WB-MRI scores (ICC 0.96 and 0.98 respectively). Both scores showed excellent correlations with clinical measures of disease activity (Manual Muscle Test (MMT) $\mathrm{r}_{\mathrm{s}}=-0.82$, Childhood Myositis Assessment Scale (CMAS) $\mathrm{r}_{\mathrm{s}}=-0.83$ for thigh-MRI; MMT $r_{\mathrm{s}}=-0.84$, CMAS $\mathrm{r}_{\mathrm{s}}=-0.81$ for WBMRI). Thigh and WB-muscle scores were significantly higher in JDM active patients when compared with the control group ( $\mathrm{pb}<0.0001$ for both the scores) and the inactive patients (thigh-MRI pb $=0.0022$, WB-MRI pb $=$ 0.0037). Responsiveness to change was higher for WBMRI muscle score (standardized response mean $=1.65$ ) compared to that of thigh MRI score $(\mathrm{SRM}=1.04)$ and to those of clinical muscle tests (SRM-CMAS $=0.56$, SRM$\mathrm{MMT}=0.74$ ).

\section{Conclusion}

WB-MRI enables a reliable analysis of the site and magnitude of inflammatory process throughout the entire body thus providing a complete assessment of total inflammatory 
burden. WB-MRI was more accurate than localized MRI in identifying myofascial and subcutaneous inflammation and in the assessment of the responsiveness to change.

\section{Disclosure of interest}

None declared.

\section{Authors' details}

${ }^{1}$ Pediatrics, Istituto G. Giannini, Genova, Italy. ${ }^{2}$ Radiology, Istituto G. Giannini, Genova, Italy.

Published: 5 December 2013

doi:10.1186/1546-0096-11-S2-P141

Cite this article as: Madeo et al:: PReS-FINAL-2129: Whole-body versus localized magnetic resonance imaging in the assessment of juvenile dermatomyositis. Pediatric Rheumatology 2013 11(Suppl 2):P141.

Submit your next manuscript to BioMed Central and take full advantage of:

- Convenient online submission

- Thorough peer review

- No space constraints or color figure charges

- Immediate publication on acceptance

- Inclusion in PubMed, CAS, Scopus and Google Scholar

- Research which is freely available for redistribution

Submit your manuscript at www.biomedcentral.com/submit 